\title{
55th National Conference of Indian Academy of Pediatrics 4-7 January 2018, Nagpur
}

\author{
Santosh T Soans \\ National President, Indian Academy of Pediatrics,2018.drsoans62@gmail.com
}

$\mathrm{R}$ espected Chief guest Shri Nitin Gadkariji, esteemed dignitaries and guests, fellow office bearers, my beloved Indian Academy of Pediatrics (IAP) members from far and near, friends, ladies and gentlemen. At the outset, I wish to confess that one's formal installation as the President of a prestigious national body is always a moment of personal glory for the incumbent, and no pretense of humility can hide the joy and thrill one feels on this momentous occasion.

But never in my wildest thoughts had I ever imagined that this intimate moment of mine would be made so much more memorable by the distinguished presence of Shri Nitin Gadkariji, Honorable Union Minister for Road Transport \& Highways, Shipping and Water Resources, River Development \& Ganga Rejuvenation. Hence with the deep respect, I wholeheartedly thank you sir for gracing this occasion with your blessings. I might also add here that, as the new President of IAP, I solicit your continued support for shaping a better future for our profession through collaborative effort with the government, which I shall present in greater detail later on in my speech.

Life, they say, is a series of moments. And every moment in itself, is an opportunity to make a fresh new beginning. Friends, today I stand before you with a dream to make a fresh new beginning for IAP. A dream that nurtures a new vision for our organization based on our commonly held, time honored ethos of harmony, growth and fraternity. A dream that is idealistic, inclusive and progressive. A dream which honors our glorious past, pragmatically embraces the present, and envisions the infinite future with imagination and determination.

As I stand before you, my thoughts go out to a day not long ago when my initial attempt to serve you in this capacity was defeated by a humble margin of only 13 votes. Indeed, it was a situation of being 'so close, yet so far.' At that downcast juncture, when I pondered over the unfortunate outcome, brought on that too by a socalled 'unlucky number 13', it was the spontaneous encouragement that come from so many of you who cared for me, which motivated me not to lose faith, but instead to persevere further. Therefore this moment is all the more precious for me because it has not only reinforced my self confidence but also my faith in my fellow IAPians. This is surely is one soul-enriching experience that neither money nor fame can buy, and I am immensely grateful to each of you.

My thoughts also go back five decades, when I began my life journey as a playful little boy in the small coastal town of Kundapur, which is situated about 90 kilometers from my present hometown of Mangalore. At that time, I never dreamed that I would one day be so fortunate as to one day share my life with you all. Like other kids of my age, all I wanted was to live happy. My life-changing moment came much later when, as a young and upcoming doctor, one day I decided to join IAP with the mentoring of Prof Sanjeev Rai. The ideals of this great organization and the opportunities it gave me for rendering service to my profession fascinated me and inspired me to wholeheartedly involve in all of IAP's multifaceted activities. Now, three decades into the timeline, I have reason enough to be grateful to this national body for recognizing my potential and giving me opportunities for continuous growth culminating with the trusteeship of this high office.

Friends, today, I am proud to lead an organization that draws on the combined talents of 27,000 members from across India, each of whom is a gifted professional in his or her own right. It has truly been my privilege to know a great many of you personally who have enriched my life in ways too many. Those whom I am yet to meet, it shall be my endeavor to do so in the years ahead.

It has been my long-held belief that 'A good leader is not one who attracts more followers, but rather, it is the one who creates more leaders.' In the highly federal structure that we have as a national body, it is the hundreds of sub units, made up of the specialist cells and specialty chapters, the regional, state level, district level and city levels units that form the pillars of strength for 
IAP. Each of these units throws up numerous opportunities for nurturing leadership at every level. Little drops of waters make up an ocean. Likewise, the essence of the IAP universe gets enriched from the valuable inputs from each of you.

Hence, as I hereby accept this rare honor to lead the Academy as the National President for the year 2018, I invite each and every one of you to join hands with me and assume leadership in our noble quest for creating a better future for IAP. This is not only a personal gesture of my deepest gratitude to you all for reposing your confidence in me in such an overwhelming manner electorally, but also it is my own way of fulfilling a promise that I made to you through the slogan 'TOGETHER LET US BUILD IAP.'

Organizations are only as great as the people who make it up. So in a profound sense, IAP needs you more than you need IAP. Today we are straddling a unique point in our organization history. Having completed 55 years of seamless growth spearheaded by stalwarts all along, the responsibility is now ours to take the big leap forward. Global advances in technology are fast outpacing us. The boom in medical education is adding an unprecedented number of young pediatricians to our profession every day. There is a huge spurt in lady doctors too. The rapid economic progress and the accelerating urbanization of our country is pushing a larger segment of the population towards our care. We shall be failing in our duty if we do not recognize these emerging realities and respond with strategy and precision to realize their dreams and aspirations, their hopes and expectations. Let us look upon the present phase as the better half of our centennial milestone and strive to develop IAP with a tough long-term vision.

In this context, I must refocus on the Academy's primary role as an academic body dedicated to the cause of research, gathering and dissemination of knowledge. Regrettably, in the course of the recent decade, core academics has taken a back seat. Hence the need of the hour is to give more impetus to intense academic activity and create the new organizational structures required to facilitate the desired outcome.

On a more reflective note, our organization has gone through many ups and downs. And there have been bad experiences and there have been times of struggle. Such instances, when they occur can have a demoralizing impact on the organization as a whole. Fortunately, we have also found the internal strength to overcome every crisis whenever it came up. In large organizations, conflicts and differences of opinion are unavoidable despite everyone's best efforts to prevent them. Such instances should always be resolved in a democratic manner and we should also develop a sporting spirit to forget the past, to shed any bitterness, and work towards the future without loss of enthusiasm. Remaining disheartened can never be a worthwhile solution. Hence our immediate goal should be strike for restoring our internal harmony and credibility keeping the organization's best interests in mind.

It is in the overall backdrop of these determining factors, that this year I have decided to take the innovative path and solicited the co-operation of President Elect Dr Digant Shastri to formulate the first ever 'Joint Presidential Plan' which will include the combined goals of both our terms of Presidency. The objective of this experiment is to ensure perpetual continuity of vision and also to give the future Presidents the chance to provide better leadership by invoking the confidence of both their successors and their predecessors. In short, this is an attempt to bridge the Past-Present-Future into one continuum. This plan which comprises 31 individual agendas is designed for the integrated development and the resurgence of our mother body into a thriving new entity, which is member-centric, issue-based and futuristic in orientation. Dear IAPians, having presented this 'Joint Presidential Plan', I solicit support from each of your for its successful outcome.

More particularly, at this juncture, I call upon Shri Nitin Gadkariji, Honourable Cabinet Minister to extend his best possible help in improving our Academy's interface with the government. Our Honourable Prime Minister Shri Narendra Modiji has won the heart of every Indian through his visionary leadership. On this august occasion, I request you sir to lend us your good offices and the benefit of the close rapport that you enjoy with the Prime Minister to lead our delegation to him and enable us to contribute to nation building through our professional expertise. We pediatricians are the privileged members of the medical professional who nurture the future generation. The nation has a great responsibility for their best care, and we as a national apex body of pediatricians are ready to render whatever assistance is required to improve the child health indices.

Moreover, as you would be aware, medical discipline has lately been facing immense challenges. We can overcome these challenges only with government's support. Hence we also look forward to your sympathetic understanding and wise counsel in effectively addressing the many issues that confront us at the governmental level.

In conclusion, I wish to express my gratitude to those 
dear to me - my family members who continue to sacrifice a lot for my sake, my friends who stand by me like a rock, my management, colleagues and student body of AJIMS who have readily supported me in all my endeavors, all the past presidents of IAP and my immediate predecessor Dr. Anupam Sachdeva for their constant guidance, my teammates, especially President Elect Dr Digant Shastri, Honorary Secretary General Dr Bakul Parekh, Treasurer Sandeep Kadam, all EB members of 2017, 2018 and office bearers of all IAP units whose support I shall always need; Central Office staff who strive for me day in and day out.
No venue would have been better for my installation than Nagpur, and I congratulate the entire IAP fraternity of Maharashtra and Nagpur in particular on hosting this conference under the leadership of Dr Uday Bodhankar, Organizing Chairman Dr Vasant Khalatkar, Organizing Secretary Dr Jayant Upadhye, and entire team Nagpur for their organizational skills.

And most importantly my deepest gratitude goes out to every IAP member on the rolls.

'TOGETHER LET US BUILD IAP'

Jai IAP, Jai Hind. 